\title{
EFFECT OF ACCELERATED AGEING ON GERMINATION AND SEEDLING VIGOUR OF MANUALLY AND MECHANICALLY HARVESTED AND THRESHED RICE SEEDS
}

\author{
M. GOVINDARAJ ${ }^{1}$, P. MASILAMANI ${ }^{2}$, P. SELVARAJU ${ }^{3} \&$ V. ALEX ALBERT ${ }^{4}$ \\ ${ }^{1,2,4}$ Agricultural Engineering College and Research Institute, TNAU, Kumulur, Tiruchirappalli, Tamil Nadu, India \\ ${ }^{3}$ Seed Centre, Tamil Nadu Agricultural University, Coimbatore, Tamil Nadu, India
}

\begin{abstract}
The study was conducted at Department of Seed Science and Technology, Tamil Nadu Agricultural University, Coimbatore during kharif 2016 to find out the effect of accelerated ageing on germination, seedling vigour and biochemical constituents of manually and mechanically harvested and threshed rice varieties viz., CR1009 Sub 1, improved white ponni and CO51. The germination, seedling vigour, dehydrogenase and alpha amylase activity was high in fresh seeds compared to aged seeds in all the varieties in different methods of harvesting and threshing at different intervals after accelerated ageing. Among the varieties CR1009 Sub 1 recorded the maximum germination, seedling vigour and biochemical constituents followed by CO51, while improved white ponni recorded minimum. Among the treatments manual harvesting and threshing registered the maximum germination and seedling vigour followed by combine harvesting, the minimum was recorded in manual harvesting and mechanical threshing. The electrical conductivity of seed leachates gradually increased by the period of accelerated aging and was high in 20 days of ageing in all the varieties. The increase in EC was more in CR1009 Sub $1\left(109.6 \mu \mathrm{Sm}^{-1}\right)$, followed by CO51 $\left(95.3 \mu \mathrm{Sm}^{-1}\right) \mathrm{and}^{-1}$ improved white ponni $\left(93.3 \mu \mathrm{Sm}^{-1}\right)$.
\end{abstract}

KEYWORDS: Rice, Accelerated Ageing, Seed Germination \& Seedling Vigor

Received: May 10, 2017; Accepted: Jun 03, 2017; Published: Jun 27, 2017; Paper Id.: IJASRAUG20176

\section{INTRODUCTION}

Rice is an important global food crop and provides food security for many countries. As the world's population continues to grow to 10 billion by 2050, the demand for rice will grow faster than for other crops because population growth is greatest in the rice-consuming and rice-producing regions of Asia, Africa, and the America (Dawe, 2007; Easterling et al., 2007). India has the largest area under rice in the world and ranks second in the production after China. India has also emerged as a major rice consumer. In India, rice is cultivated in an area 43.95 Mha, producing 106.54 MT at a productivity of $2424 \mathrm{~kg} / \mathrm{ha}$. In Tamil Nadu rice area 1.79 Mha, production $5.54 \mathrm{MT}$ and productivity $3700 \mathrm{~kg} / \mathrm{ha}$ (India stat, 2016). Seed quality is the most important factor influencing crop growth, development, and yield processes. Harvesting, threshing and cleaning play a significant role in realizing the full benefit of raising crop by reducing post-harvest losses as well as improving quality of rice. These operations play a vital role in protecting seed viability/germination. Improper harvesting, threshing and cleaning may cause loss of seed germination/viability. Before recommending the best adoptable harvesting and threshing methods, we need to understand their effect on seed quality viz., germination percentage and seedling vigor etc. 
The accelerated aging test is a stress test. The seeds are stressed prior to the germination test. Seeds are placed in temperature of $40 \pm 1^{\circ} \mathrm{C}$ and nearly $100 \%$ relative humidity for varying lengths of time, depending on the kind of seeds, after which a germination test is made. The basis for this test is that higher vigor seeds tolerate the high temperature-high humidity treatment and thus retain their capability to produce normal seedlings in the germination test. It was first developed by Delouche (1965) quoted in AOSA (1983) for seed longevity. Since then several researchers have carried out and aging treatment has been recommended for a wide range of crop species (AOSA, 1983). Accelerated ageing test has good correlation to field emergence and storage potential of the seed. In order to evaluate the storage potential of different varieties, accelerated ageing test is being employed in different crops. A uniform accelerated ageing procedure has not been developed for testing rice (Oryza sativa L.) seed obtained from different harvesting and threshing methods. The duration of accelerated ageing, the time taken to reduce the germination potential to $50 \%$ of the initial, varies with manually and mechanically harvested and threshed rice varieties. The results obtained from this test may be correlated with natural ageing/storage. In this context, an attempt was made to study the effect of accelerated aging on germination, seedling vigor and biochemical constituents of manually and mechanically harvested and threshed rice varieties.

\section{MATERIALS AND METHODS}

An experiment was conducted at the Department of Seed Science and Technology, Tamil Nadu Agricultural University, Coimbatore, Tamil Nadu during kharif, 2016 to find out influence of accelerated ageing on germination, seedlings vigor and biochemical changes of seeds obtained from the following harvesting and threshing methods in three different rice varieties of CR1009 Sub1, IW Ponni and CO51 at physiological maturity stage with a moisture content of $22.5 \%, 19.45 \%$ and $18.60 \%$ respectively. The treatments are manual harvesting and manual threshing $\left(\mathrm{T}_{1}\right)$, manual harvesting and mechanical threshing (axial flow thresher) $\left(\mathrm{T}_{2}\right)$ and combine harvester (with pneumatic wheel) $\left(\mathrm{T}_{3}\right)$. The harvested and threshed seeds were sun dried to reduce the seed moisture to 12 percent and processed using a cleaner cum grader. Twenty five grams of processed seeds were covered with a butter paper cover and placed in the desiccators. The desiccators were placed in an accelerated aging chamber maintained at $40^{\circ} \mathrm{C}$ and $100 \%$ relative humidity at specified intervals $(0,1,2,3,4,5,6,7,8,9,10,11,12,13,14,15,16,17,18,19$ and 20 days) during the accelerated ageing process. Treatment wise seeds were soaked in double of its volume in water for 16 hours and analyzed electrical conductivity. Dehydrogenase activity and Alpha-amylase enzyme activity were also estimated treatment wise. The accelerated aged and control seeds were then placed for germination in roll towel method. The experiment was conducted in a factorial completely randomized block design. Under each treatment, 400 seeds were sown with eight replications of 50 seeds each. Seed germination was expressed as the percentage of seeds producing normal seedlings. Fourteen days after sowing (ISTA, 2011) ten seedlings from each replication were randomly selected and the root and shoot lengths were measured and the mean was recorded. Ten random seedlings were dried in a hot air oven at $85^{\circ} \mathrm{C}$ for 24 hours. And the dry weight was recorded and expressed as g/10 seedling. The vigor index was calculated using the following formula (Abdul - Baki and Anderson, 1973)

Vigor Index $=$ Percentage germination $\mathrm{x}$ Total seedling length $(\mathrm{cm})$.

The results were subjected to statistical analysis for significant difference $(\mathrm{p}=0.05)$ as per Panse and Sukhatme (1995). Percentage values were transformed using arc sine values prior to statistical analysis. 


\section{RESULTS AND DISCUSSIONS}

Significant changes in seed germination were observed due to duration of accelerated ageing, treatments and varieties. The seed germinates in fresh seeds (95\%) declined gradually to increase in ageing duration and reached the minimum at 20 days of accelerated aging (19\%) (Table 1, Figure 1). Among the treatments, manual harvesting and threshing registered the maximum seed germination (64\%) followed by combine harvester (61\%), the minimum germination of 57 per cent registered in manual harvesting and mechanical threshing. Among the varieties, CR1009 Sub 1 recorded the maximum germination (66\%) while improved white ponni recorded the minimum germination (53\%). There was a significant progressive reduction in germination percent with increase in duration of accelerated ageing in rice genotypes by Somasundaram and Bhaskaran (2017). Vijayakumar and Vijayakumar (2015) in soybean and Kanakadurga et al. (2012) in pigean pea. Accelerated aging is a physiological stress test that permits controlled deterioration of seeds due to exposure of seeds to high temperature and high relative humidity (greater than $90 \%$ ). Seed moisture content and high temperature influence seed metabolism. High relative humidity increases seed moisture, which results in biochemical events such as increased hydrolytic enzyme activity and free fatty acids where as high temperature serves to enhance the rate at which many enzymatic and metabolic reactions occurs and thereby increases the metabolic activity of hydrolyzed substrates and enzymes causing more rapid rate of deterioration (Khan et al., 2010). Further, during seed deterioration, the free radicals generated as a result of lipid peroxidation cause damage to enzymes that are necessary to convert reserve food in the embryo to a usable form and thereby affects production of normal seedling (Iqbal et al., 2002) and these free radicals also degrade mitochondrial membrane leading to reduction in energy supply necessary for germination thereby cause failure in seed germination (Gidrol et al., 1998).

Root length and shoot length were significantly influenced by accelerating ageing duration, treatments and varieties (Table 2 and 3). The root length of varieties before accelerating ageing ranged from $23.5 \mathrm{~cm}(\mathrm{CO} 51)$ to $23.9 \mathrm{~cm}$ (CR1009 Sub 1) where as shoot length ranged from $10.6 \mathrm{~cm}$ (improved white ponni) to $11.4 \mathrm{~cm}$ (CR1009 Sub 1). Root length and shoot length were significantly decreased after each period of accelerated ageing. But the rate of reduction did not vary significantly among the varieties. Among the treatments, manual harvesting and threshing registered the longest root length $(17.1 \mathrm{~cm})$ while manual harvesting and mechanical threshing registered the shortest root length $(15.3 \mathrm{~cm})$. Among the varieties, CR1009 Sub 1 recorded the longest root length $(17.8 \mathrm{~cm})$ while improved white ponni recorded the shortest root length $(14.1 \mathrm{~cm})$. Regarding shoot length manual harvesting and threshing registered the longest shoot $(8.0$ $\mathrm{cm})$ while manual harvesting and mechanical threshing registered the shortest shoot $(6.8 \mathrm{~cm})$. Among the varieties, CR1009 Sub 1 recorded the longest shoot $(8.6 \mathrm{~cm})$ while improved white ponni recorded the shortest shoot $(6.1 \mathrm{~cm})$. The findings of this study are consistent with the findings of Rame Gowda (1992) in rice, Nautilyl et al. (1997) in peanut, Kanakadurga et al. (2012) in Pigeon pea and Rajendraprasad (2014) in sunnhemp. Reduced seedling growth due to accelerated ageing is mainly due to both lower respiration and reduced mitochondria in cells (McDonald, 1999).

Dry matter production and vigor index were significantly influenced by accelerating ageing duration, treatments and varieties (Table 4 and 5, Figure 1). The dry matter production before accelerating ageing ranged from $0.112 \mathrm{~g} / 10$ seedlings (Improved white ponni) to $0.147 \mathrm{~g} / 10$ seedlings (CR1009 Sub 1). Dry matter production decreased significantly over the duration of accelerated ageing. Among the treatments, manual harvesting and threshing registered the maximum dry matter $(0.121 \mathrm{~g} / 10$ seedling) while the minimum was recorded in manual harvesting and mechanical threshing $(0.115$ $\mathrm{g} / 10$ seedling). Among the varieties, CR1009 Sub 1 recorded the maximum dry matter $(0.143 \mathrm{~g} / 10 \mathrm{seedling})$ and the 
minimum was (0.096 g/10 seedling) observed in an improved white ponni. However, dry matter production ceased in improved white ponni which was harvested manually and threshed mechanically from 18 days of accelerated ageing. Reduction in dry matter production due to accelerated aging test is mainly because of poor seedling development (Mosaviet al., 2011). Among the treatments, manual harvesting and threshing registered the highest vigor index (1757) while manual harvesting and mechanical threshing registered the lowest vigour index (1465). Among the varieties, CR1009 Sub 1 recorded the highest vigor index (1851) while improved white ponni recorded the lowest vigour index (1343). Reduced capacity to germinate and produce vigorous seedlings is the main reason for decreased vigor index due to accelerated ageing of seed (Singh, 1989). Similar conclusion on growth efficiency and seedling vigor as a result of ageing effects with regard to varietal responses was also reported by several workers (Kalpana and Rao, 1995; Gowda et al., 2002; Kapoor et al., 2010)

Electrical conductivity of seed leachates was significantly influenced by duration of accelerated ageing, seed treatments and varieties (Table 6). Irrespective of the treatment and varieties, the lowest electrical conductivity was observed in unaged seeds $\left(60.1 \mu \mathrm{Sm}^{-1}\right)$ and increased gradually with increase in duration of accelerated ageing and reached the maximum at 20 days of ageing $\left(143.7 \mu \mathrm{Sm}^{-1}\right)$. Among the treatment, manual harvesting and threshing registered the lowest electrical conductivity $\left(96.1 \mu \mathrm{Sm}^{-1}\right)$ while the highest was recorded in manual harvesting and mechanical threshing $\left(102.4 \mu \mathrm{Sm}^{-1}\right)$. Among the varieties, improved white ponni recorded the lowest electrical conductivity $\left(93 . \mu \mathrm{Sm}^{-1}\right)$ and the highest was observed in CR1009 Sub $1\left(109.64 \mu \mathrm{Sm}^{-1}\right)$. Electrical conductivity of seed leachate is a good index of seed deterioration. Intensity of membrane damage during storage was measured by electrical conductivity of the seed leachate (Mathews and Bradnock, 1968). Parrish and Leopold (1978) determined that free radicals, which are very harmful to living cells, are produced in cell membranes when exposed to accelerated ageing, and may cause membrane damage resulting in ion leakage (as determined via electrical conductivity).

Among the accelerated ageing duration, dehydrogenase and alpha amylase activity declined to increase with the ageing duration and reached the minimum at 20 days of accelerated ageing (Table 7 and 8). Among the varieties, CR1009 Sub 1 recorded the maximum dehydrogenase activity (0.891) while the minimum was observed in improved white ponni (0.776). Kranshook et al. (1978) expressed that the loss in viability in rice seed was accompanied by changes in lipid and protein complexes in seed cells and associated decrease in energy potential which depended on changes in dehydrogenases, oxidases and the enzymes participating in respiration. Regarding alpha amylase activity, among the treatments, manual harvesting and threshing recorded the maximum activity (1.567) while the minimum was observed in manual harvesting and mechanical threshing (1.493). Among the varieties, CR1009 Sub 1 registered the maximum $\alpha$-amylase activity (1.641) while the minimum was recorded in CO51 (1.460). Rame Gowda (1992) reported a decrease in the activity of enzymes viz., $\alpha$-amylase, catalyze and peroxides, coupled with progressive ageing of rice seeds.

In general, mechanical injury during harvesting, threshing, cleaning, handling and plating is considered as one of the most important factors influencing seed quality and thus seeds and seedling vigor. In the present study irrespective of the variety studied manual harvesting and mechanical threshing registered reduced germination, seedling vigor and biochemical constituents when compared to manual harvesting and manual threshing and combine harvesting. This may be due to at the time of threshing, increased cylinder speeds of thresher cause mechanical damage, especially ruptures which caused restriction of nutrient translocation to the embryonic axis caused seed and seedling abnormalities. 


\section{CONCLUSIONS}

Accelerated ageing on germination, seedling vigor and biochemical constituents of manually and mechanically harvested and threshed rice varieties revealed that their ability to germinate and produce vigor's seedlings which are mainly due to varied resistance to deteriorative changes. Seed germination per cent in CO51 and CR1009 Sub 1 reduced to around 50 per cent of their initial by 14 days of accelerated ageing, where as improved white ponni reduced to around 50 per cent of their initial by 11 days of accelerated ageing. Hence 15 days of accelerated ageing is considered as optimum duration of ageing for manually and mechanically harvested rice varieties.

\section{REFERENCES}

1. Abdul-Baki, A.A. and Anderson, J.D. (1973). Vigour deterioration of soybean seeds by multiple criteria. Crop Sci., 13: 630633.

2. Association of Official Seed Analysts. (1983). Seed vigor testing handbook. Contribution No. 32. Association of Official Seed Analysts. Lincon, NE., USA.

3. Dawe, D. (2007). Agricultural research, poverty alleviation and key trends in Asia's rice economy. In Charting New Pathways to $C_{4}$ Rice. International Rice Research Institute, the Philippines. 37-53.

4. Delouche, J.C. (1965). An accelerated aging technique for predicting relative storability of crimson clover and tall fescue seed lots. Agron. Abstr., 40.

5. Gidrol, X., Noubhani, A., Mocquot, B., Fournier. A and Pradet, A. (1998). Effect of accelerated aging on protein synthesis in two legume seeds. Plant Physio. Biochem. 26: 281-288.

6. Gowda, R., Swarna, C., Deveraja, P.J. and Vidya Chandra, B. (2002). Evaluation of rice hybrid KRH-2 and its parental lines for their storability by natural and accelerated ageing. Current Research University of Agricultural Sciences Bangalore, 31: $62-65$.

7. Iqbal, N., Shahzad, A., Basra, M. and Rehman, K.U. (2002). Evaluation of vigor and oil quality in cotton seed during accelerated aging. Int. J. Agri. Biol., 4: 318-322.

8. ISTA. (2011). International rules for seed testing. International Seed Testing Association, Bassersdorf, Switzerland.

9. Kalpana, R. and Rao, K.V. (1994). Absence of the role of lipid peroxidation during accelerated ageing of seeds of pigeonpea (Cajanus cajan L. Millsp.). Seed Sci. \& Technol., 22: 253- 260.

10. Kanaka Durga, K., Kesavalu, K., Jyothi, M., Ankaiah, R. and Ganesh, M. (2012). Effect of accelerated ageing on germination and vigour in pigeonpea (Cajanus cajan. Seed res., 40: 34-40.

11. Kapoor, N., Arya, A., Siddiqui, M.A., Amir, A. and Kumar, H. (2010). Seed deterioration in chickpea (Cicer arietinum L.) under accelerated ageing. Asian J. Plant Sci., 9: 158-162.

12. Khan, A.Z.P., Shah, F., Khan, M.H., Amanullah, S., Perveen, S., Nigar, S.K. and Zubair, M. (2010). Vigour tests used to rank seed lot quality and predict field emergence in wheat. Pak. J. Bot. 42: 3147- 3155.

13. Kranshook, N.P., Vishnyakova, I.A., Povarova, R.I. and Bukhtoyarova, A. T. (1978). Biochemical changes in rice sseeds associated with loss of viability. Vavilora, 77: 26-30.

14. Mathews, S. and Bradnock, W.T. (1968). Relationship between exudation and field emergence in peas and French beans. Hort. Res., 8: 89-93. 
15. Mc Donald, M.B. (1999): Seed deterioration: physiology, repair and assessment Seed Sci. \& Technol., 27: 177-237.

16. Mosavi N.S.M., Gholami, H., Kord, G.H., Sadeghi, M., Sedighi, E. (2011). Free fatty acid and electrical conductivity changes in cotton seed (GossypiumhirsutumL.). Internat. J. Agri. Sci., 1: 62-66

17. Nautityle, P., Ravindra, C.V. and Misra, J.B. (1997). Response of dormant and non-dormant seeds of groundnut (Arachis hypogea) genotype to accelerated ageing. Indian. J. Agr. Sci., 67: 67-70.

18. Panse, V.G. and Sukhatme, P.V. (1995). Randomized design and square and factorial experiment in statistical methods of Agricultural workers (2 nd Edn.) ICAR, New Delhi.

19. Parrish, D.J. and Leopold, A.C. (1978). On the mechanism of aging in soybean seeds. Plant Physiol., 61: 365-368.

20. Rajendra Prasad, S. (2014). Effect of mother crop nutrients on seed production and quality in sunn hemp (Crotalaria juncea L.) M.Sc(Ag) Thesis. Tamil Nadu Agricultural University, Agricultural College and Research institute, Madurai

21. Rame Gowda. (1992). Studies on seed senescence and seed vigour in some genotypes of rice (Oryza sativa L.). Ph.D. Thesis, Tamil Nadu Agricultural University, Coimbatore.

22. Singh, A.K. (1989). Effect of storage temperature and relative humidity on seed germinability of soybean seed. Seed Res., 15:104-105.

23. Somasundaram, G. and Bhaskaran, M. (2017). Standardization of accelerated ageing duration for screening of rice genotypes for seed longevity. International Journal of Agricultural Science and Research, 7: 397-404

24. Vijayakumar, H.P and Vijayakumar, A. (2015). Standardization of accelerated ageing duration to evaluate seed storability of soybean cultivars. International Journal of Agricultural Science and Research, 5:93-98.

25. https://www.indiastat.com.

\section{APPENDICES}

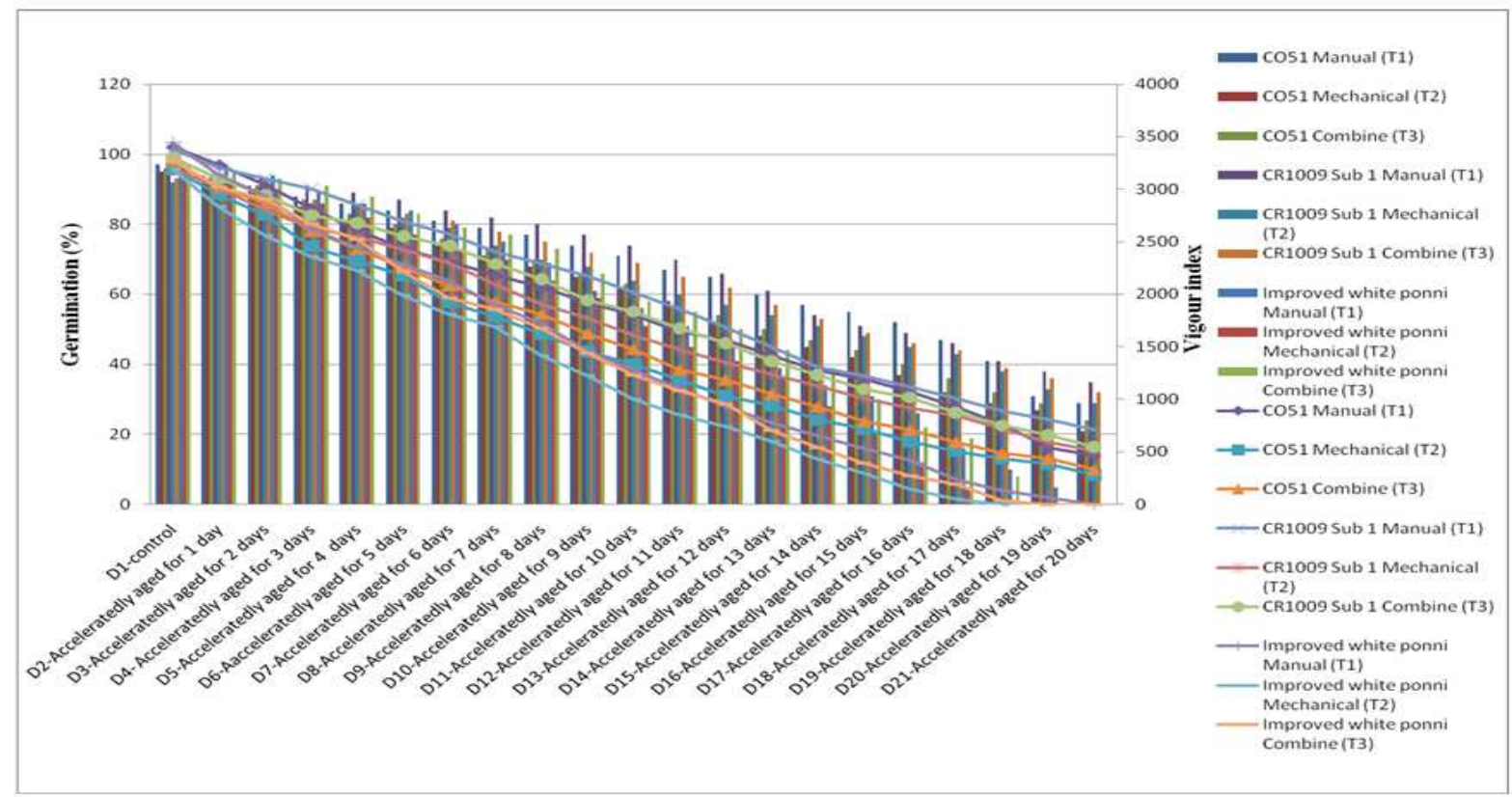

Figure 1: Effect of Accelerated Ageing on Germination (\%) and Vigour Index of Manually and Mechanically Harvested and Threshed Rice Varieties 
Table 1: Effect of Accelerated Ageing on Germination (\%) of Manually and Mechanically Harvested and Threshed Rice Varieties

\begin{tabular}{|c|c|c|c|c|c|c|c|c|c|c|c|c|c|}
\hline \multirow{2}{*}{$\begin{array}{l}\text { Accelerated } \\
\text { Ageing in } \\
\text { Davs (D) }\end{array}$} & \multicolumn{4}{|c|}{$\cos (\mathrm{Vl})$} & \multicolumn{4}{|c|}{ CR1009 Sub l (V2) } & \multicolumn{4}{|c|}{ Improved White Ponni (V3) } & \multirow{2}{*}{$\begin{array}{l}\text { Grand } \\
\text { Mean }\end{array}$} \\
\hline & $\mathrm{T}_{1}$ & $\mathrm{~T}_{2}$ & $\mathrm{~T}_{3}$ & Mean & $\mathrm{T}_{1}$ & $\mathrm{~T}_{2}$ & $\mathrm{~T}_{3}$ & Mean & $\mathrm{T}_{1}$ & $\mathrm{~T}_{2}$ & $\mathrm{~T}_{3}$ & Mean & \\
\hline$D_{1}$ & $97(80.64)$ & $95(77.24)$ & $96(79.41)$ & $(79.41)$ & $95(78.19)$ & $92(75.44)$ & $93(75.06)$ & $93(75.06)$ & $98(82.80)$ & $96(79.41)$ & $97(80.63)$ & $(80.63)$ & $95(77.24)$ \\
\hline $\mathrm{D}_{2}$ & $(76.96)$ & $93(76.23)$ & $94(76.96)$ & $94(76.96)$ & $94(76.02)$ & $90(72.05)$ & $92(75.44)$ & $92(75.44)$ & $97(80.63)$ & $92(74.10)$ & $95(77.24)$ & & \\
\hline $\mathrm{D}_{3}$ & $(72.88)$ & $89(70.69)$ & $91(72.88)$ & $90(72.05)$ & $93(75.06)$ & $88(70.48)$ & $90(72.05)$ & $90(72.05)$ & $94(76.96)$ & $89(70.83)$ & $93(76.27)$ & $92(75.44)$ & \\
\hline $\mathrm{D}_{4}$ & $8(70.47)$ & $85(67.59)$ & $87(69.25)$ & $87(69.25)$ & 91 (72.88) & $86(69.04)$ & $87(69.52)$ & $88(70.47)$ & $89(70.69)$ & $86(68.69)$ & $91(72.88)$ & $89(70.69)$ & \\
\hline $\mathrm{D}_{5}$ & $(68.29)$ & $81(64.24)$ & $83(65.76)$ & $83(65.76)$ & $89(70.83)$ & $85(67.81)$ & $86(68.56)$ & $87(69.25)$ & $86(68.29)$ & $82(6533)$ & $88(70.47)$ & & \\
\hline $\mathrm{D}_{6}$ & $(66.77)$ & $79(62.97)$ & $80(63.63)$ & & $7(69.25)$ & $82(65.33)$ & $83(66.12)$ & $84(66.77)$ & $84(66.77)$ & $77(61.51)$ & $83(65.76)$ & & \\
\hline$\frac{D_{7}}{2}$ & $(64.23)$ & $74(59.57)$ & $76(61.01)$ & & $4(67.25)$ & $79(62.84)$ & $81(64.75)$ & $81(64.75)$ & $80(63.63)$ & $73(58.82)$ & $79(62.97)$ & & \\
\hline $\mathrm{D}_{8}$ & $(62.97)$ & $71(57.51)$ & $73(58.82)$ & & $(65$ & $74(59.43)$ & $78(62.44)$ & $78(62.44)$ & $75(60$. & $70(57.00)$ & $77(61.52)$ & & \\
\hline $\mathrm{D}_{9}$ & $7(61.52)$ & $68(55.57)$ & $70(57.00)$ & $72(58$ & $80(63.72)$ & $70(56.85)$ & $75(60.40)$ & $75(60.40)$ & $69(56.37)$ & $64(53.21)$ & $73(58.98)$ & & \\
\hline$D_{10}$ & $4(59.57)$ & $65(53.75)$ & $66(54.34)$ & $68(55.57)$ & $77(61.69)$ & $68(55.80)$ & $72(58.35)$ & $72(58.35)$ & $61(51.40)$ & $59(50.21)$ & $66(54.50)$ & $62(52.03)$ & \\
\hline $\mathrm{D}_{11}$ & $1(57.51)$ & $62(52.03)$ & $63(52.68)$ & $65(53.75)$ & $74(59.57)$ & $64(53.25)$ & $69(56.37)$ & $69(56.37)$ & $56(48.50)$ & $51(45.58)$ & $58(49.66)$ & $55(47.88)$ & $63(52.68)$ \\
\hline$D_{12}$ & $(54.97)$ & $58(49.62)$ & $56(48.46)$ & & $70(56.95)$ & $60(50$ & $65(53.91)$ & & $51(4$ & $45(42.08)$ & $55(47.88)$ & & \\
\hline$D_{13}$ & $(53.75)$ & $52(46.16)$ & $54(47.31)$ & & $66(54.45)$ & $57(49.08)$ & $62(52.03)$ & & $46(42.68)$ & $41(39.71)$ & $50(45.02)$ & & \\
\hline $\mathrm{D}_{14}$ & $(50.82)$ & $48(43.85)$ & $50(45.00)$ & & $61(51.48)$ & $54(47.31)$ & $57(49.08)$ & & $39(38.61)$ & $36(36.81)$ & $44(41.53)$ & & \\
\hline $\mathrm{D}_{15}$ & $(49.04)$ & $45(42.12)$ & $47(43.27)$ & & $54(47.31)$ & $51(45.56)$ & $53(46.75)$ & & $34(35.55)$ & $28(31.77)$ & $39(38.60)$ & & \\
\hline$D_{16}$ & $5(47.17)$ & $42(40.3)$ & $44(41.54)$ & $47(43$. & $51(45.58)$ & $48(43.85)$ & $49(44.40)$ & $49(44.40)$ & $31(33.65)$ & $20(26.22)$ & $30(33.15)$ & $27(31$ & \\
\hline $\mathrm{D}_{17}$ & $52(46.17)$ & $37(37.45)$ & $40(39.21)$ & $43(40$. & $49(44.40)$ & $45(42.12)$ & $46(42.68)$ & $47(43.27)$ & $26(30.49)$ & $12(20.14)$ & $22(27.41)$ & $20(26$ & $37(3$ \\
\hline $\mathrm{D}_{18}$ & $7(43.27)$ & $32(34.43)$ & $36(36.86)$ & & $46(42.65)$ & $43(40.92)$ & $44(41.53)$ & $44(41.53)$ & $16(23.06)$ & $510.61)$ & $19(25.59)$ & $13(19.75)$ & $32(34.43)$ \\
\hline $\mathrm{D}_{19}$ & $(39.76)$ & $29(32.55)$ & $32(34.40)$ & & $41(39.80)$ & $38(38.03)$ & $39(38.57)$ & & $10(18.35)$ & $0(2.87)$ & $8(15.90)$ & $6(1)$ & \\
\hline $\mathrm{D}_{20}$ & $(33.76)$ & $27(31.18)$ & $29(32.49)$ & & $38(37.95)$ & $33(34.93)$ & $36(36.72)$ & & & $0(2.87)$ & $0(2.87)$ & & \\
\hline$D_{21}$ & $(32.49)$ & $21(27.20)$ & $24(29.30)$ & & $35(36.09)$ & $29(32.31)$ & $32(34.27)$ & & & $0(2.87)$ & $0(2.87)$ & & \\
\hline & $8(56.91)$ & $60(51.54)$ & $6 \mathrm{l}(52.77)$ & & $69(57.93)$ & $64(53.94)$ & $66(55.67)$ & & $55(47.88)$ & $49(48.50)$ & $56(48.50)$ & & \\
\hline & $\mathrm{Tl}$ & $64(53.94)$ & & T2 & $57(49.05)$ & & T3 & & & & & & \\
\hline & 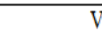 & & $T$ & & $\mathrm{D}$ & & VT & & TD & & VD & & TD \\
\hline SEd & 0.57 & & 0.5760 & & 1.5240 & & 0.9977 & & 2.6396 & & 2.6396 & & 5719 \\
\hline $\mathrm{CD}(\mathrm{P}=0.05)$ & & & 1.1363 & & 4.0063 & & 1.9681 & & NS & & NS & & NS \\
\hline
\end{tabular}

$\mathrm{T}_{1}$ - Manual harvesting and manual threshing, $\mathrm{T}_{2}$ - Manual harvesting and mechanical threshing and $\mathrm{T}_{3}$ - Combine harvester Figures in parenthesis indicate arcsine value

Table 2: Effect of Accelerated Ageing on Root Length (cm) of Manually and Mechanically Harvested and Threshed Rice Varieties

\begin{tabular}{|c|c|c|c|c|c|c|c|c|c|c|c|c|c|}
\hline \multirow{2}{*}{ Treatments } & \multicolumn{4}{|c|}{$\operatorname{CO51}(\mathrm{V} 1)$} & \multicolumn{4}{|c|}{ CR1009 Sub 1 (V2) } & \multicolumn{4}{|c|}{ Improved White Ponni (V3) } & \multirow{2}{*}{$\begin{array}{l}\text { Grand } \\
\text { Mean }\end{array}$} \\
\hline & $\mathrm{T}_{1}$ & $T_{2}$ & $T_{3}$ & Mean & $T_{1}$ & $T_{2}$ & $\mathrm{~T}_{3}$ & Mean & $\mathrm{T}_{1}$ & $\mathbf{T}_{2}$ & $\mathbf{T}_{3}$ & Mean & \\
\hline $\mathrm{D}_{1}$-control & 24.1 & 22.9 & 23.4 & 23.5 & 24.1 & 23.6 & 24.1 & 23.9 & 23.8 & 23.0 & 23.5 & 23.4 & 23.6 \\
\hline $\mathrm{D}_{2}$-Acceleratedly aged for 1 day & 23.9 & 21.7 & 22.0 & 22.5 & 23.2 & 22.5 & 22.8 & 22.8 & 22.1 & 21.1 & 22.0 & 21.7 & 22.4 \\
\hline $\mathrm{D}_{3}$-Acceleratedly aged for 2 days & 23.1 & 21.5 & 21.8 & 22.1 & 22.8 & 21.9 & 21.9 & 22.2 & 21.3 & 19.7 & 21.6 & 20.9 & 21.7 \\
\hline $\mathrm{D}_{4}$-Acceleratedly aged for 3 days & 22.3 & 20.2 & 21.1 & 21.2 & 22.5 & 20.7 & 21.5 & 21.6 & 20.0 & 18.8 & 20.3 & 19.7 & 20.8 \\
\hline $\mathrm{D}_{5}$-Acceleratedly aged for 4 days & 21.2 & 19.9 & 20.4 & 20.5 & 21.9 & 20.5 & 21.2 & 21.2 & 19.3 & 18.6 & 19.7 & 19.2 & 20.3 \\
\hline $\mathrm{D}_{6}$-Aacceleratedly aged for 5 days & 20.2 & 19.2 & 19.7 & 19.7 & 21.1 & 20.4 & 21.0 & 20.8 & 18.4 & 17.8 & 18.2 & 18.1 & 19.6 \\
\hline $\mathrm{D}_{7}$-Acceleratedly aged for 6 days & 19.7 & 18.1 & 19.1 & 19.0 & 20.7 & 20.0 & 20.8 & 20.5 & 18.2 & 17.0 & 17.0 & 17.4 & 19.0 \\
\hline $\mathrm{D}_{8}$-Acceleratedly aged for 7 days & 18.9 & 17.3 & 18.3 & 18.2 & 20.0 & 19.4 & 19.8 & 19.7 & 17.8 & 16.8 & 16.6 & 17.1 & 18.3 \\
\hline $\mathrm{D}_{9}$-Acceleratedly aged for 8 days & 18.4 & 16.3 & 17.9 & $\mathbf{1 7 . 5}$ & 19.3 & 18.7 & 19.2 & 19.1 & 17.1 & 15.4 & 16.1 & 16.2 & 17.6 \\
\hline $\mathrm{D}_{10}$-Acceleratedly aged for 9 days & 17.8 & 15.2 & 16.9 & 16.6 & 18.9 & 17.8 & 18.0 & 18.2 & 16.4 & 14.6 & 15.6 & 15.5 & 16.8 \\
\hline $\mathrm{D}_{11}$-Acceleratedly aged for 10 days & 17.1 & 14.7 & 16.1 & 16.0 & 18.2 & 17.1 & 17.9 & 17.7 & 15.9 & 14.2 & 15.4 & 15.2 & 16.3 \\
\hline $\mathrm{D}_{12}$-Acceleratedly aged for 11 days & 16.5 & 14.0 & 15.6 & 15.4 & 17.6 & 16.7 & 17.2 & 17.2 & 15.3 & 13.9 & 14.3 & 14.5 & 15.7 \\
\hline $\mathrm{D}_{13}$-Acceleratedly aged for 12 days & 16.3 & 13.8 & 15.4 & 15.2 & 17.0 & 16.1 & 16.7 & 16.6 & 14.0 & 13.0 & 13.7 & 13.6 & 15.1 \\
\hline $\mathrm{D}_{14}$-Acceleratedly aged for 13 days & 15.8 & 13.6 & 14.8 & 14.7 & 16.6 & 15.4 & 16.0 & 16.0 & 14.2 & 12.2 & 11.6 & 12.7 & 14.5 \\
\hline $\mathrm{D}_{15}$-Acceleratedly aged for 14 days & 15.0 & 12.4 & 13.9 & 13.8 & 16.2 & 15.1 & 15.7 & 15.7 & 13.4 & 11.5 & 10.0 & 11.6 & 13.7 \\
\hline $\mathrm{D}_{16}$-Acceleratedly aged for 15 days & 14.7 & 12.0 & 12.8 & 13.2 & 15.8 & 14.2 & 15.4 & 15.1 & 12.6 & 11.1 & 9.1 & 10.9 & 13.1 \\
\hline $\mathrm{D}_{17}$-Acceleratedly aged for 16 days & 13.6 & 11.3 & 12.5 & 12.5 & 15.0 & 13.7 & 14.9 & 14.5 & 11.6 & 9.3 & 8.8 & 9.9 & 12.3 \\
\hline $\mathrm{D}_{18}$-Acceleratedly aged for 17 days & 13.1 & 10.9 & 11.5 & 11.8 & 14.4 & 13.5 & 14.1 & 14.0 & 10.7 & 7.3 & 7.3 & 8.4 & 11.4 \\
\hline $\mathrm{D}_{19}$-Acceleratedly aged for 18 days & 12.3 & 10.3 & 10.3 & 11.0 & 14.2 & 12.6 & 13.1 & 13.3 & 9.0 & 0.0 & 4.4 & 4.5 & 9.6 \\
\hline $\mathrm{D}_{20}$-Acceleratedly aged for 19 days & 11.0 & 9.7 & 9.9 & 10.2 & 13.9 & 11.9 & 12.3 & 12.7 & 8.4 & 0.0 & 0.0 & 2.8 & 8.6 \\
\hline $\mathrm{D}_{21}$-Acceleratedly aged for 20 days & 10.3 & 9.0 & 9.3 & 9.5 & 13.0 & 11.3 & 11.1 & 11.8 & 0.0 & 0.0 & 0.0 & 2.5 & 7.9 \\
\hline \multirow[t]{3}{*}{ Mean } & 17.4 & 15.4 & 16.3 & 16.4 & 18.4 & 17.3 & 17.8 & 17.8 & 15.6 & 13.1 & 13.6 & 14.1 & 16.1 \\
\hline & T1 & 17.1 & & T2 & 15.3 & & T3 & 15.9 & & & & & \\
\hline & \multicolumn{2}{|c|}{$\mathrm{V}$} & \multicolumn{2}{|c|}{$\mathrm{T}$} & \multicolumn{2}{|l|}{$\mathrm{D}$} & VT & \multicolumn{2}{|c|}{ TD } & \multicolumn{3}{|c|}{ VD } & VTD \\
\hline SEd & \multicolumn{2}{|c|}{0.1489} & \multicolumn{2}{|c|}{0.1489} & \multicolumn{2}{|l|}{0.3940} & 0.2580 & \multicolumn{2}{|c|}{0.6825} & \multicolumn{3}{|c|}{0.6825} & 1.1821 \\
\hline $\mathrm{CD}(\mathrm{P}=0.05)$ & \multicolumn{2}{|c|}{0.2925} & \multicolumn{2}{|c|}{0.2925} & \multicolumn{2}{|l|}{0.7740} & 0.5067 & \multicolumn{2}{|c|}{1.3405} & \multicolumn{3}{|c|}{1.3405} & 2.3219 \\
\hline
\end{tabular}

$\mathrm{T}_{1}$ - Manual harvesting and manual threshing, $\mathrm{T}_{2}$ - Manual harvesting and mechanical threshing and $\mathrm{T}_{3}$ - Combine harvester 
Table 3: Effect of Accelerated Ageing on Shoot Length $(\mathrm{cm})$ of Manually and Mechanically Harvested and Threshed Rice Varieties

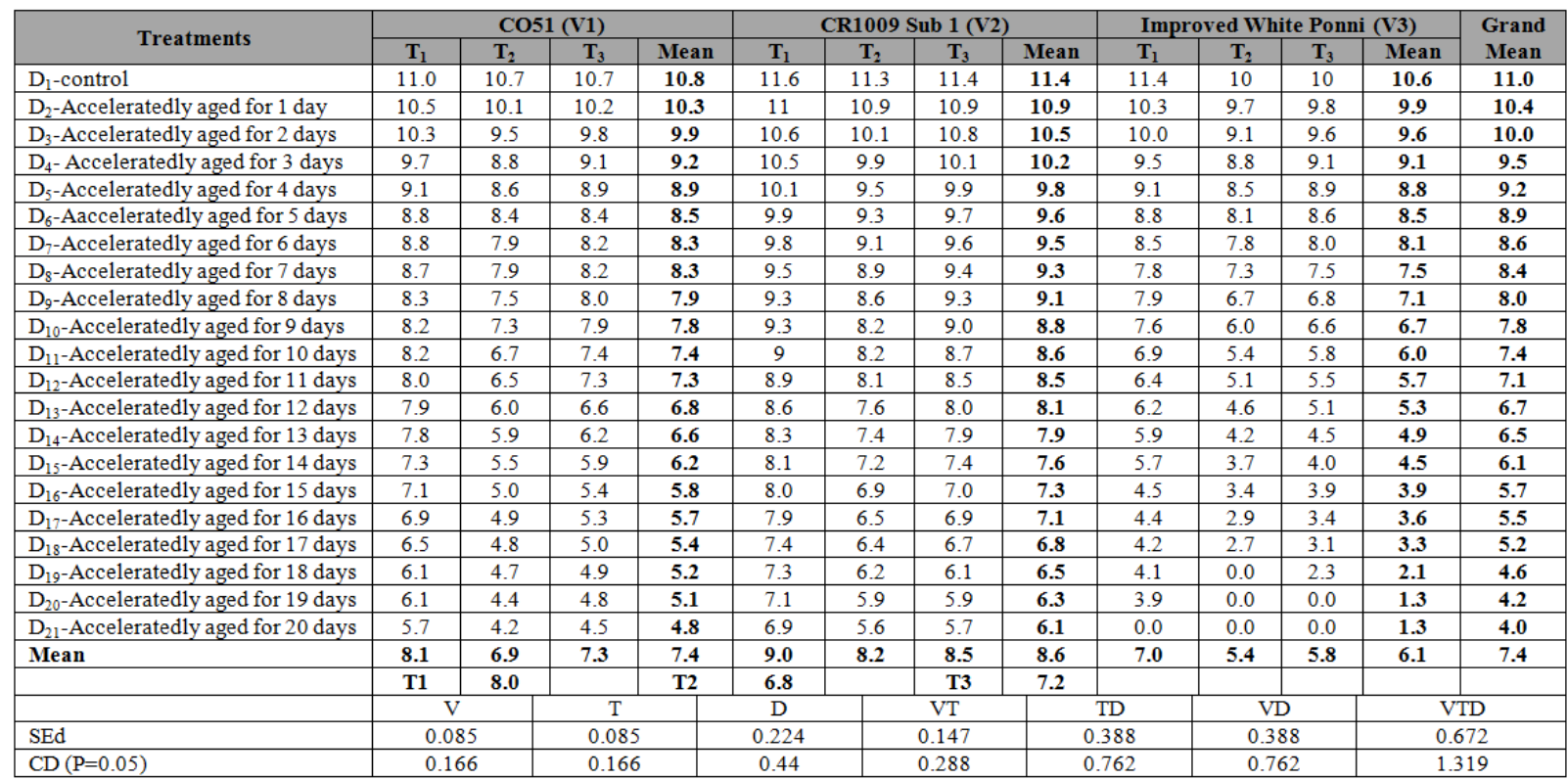

$\mathrm{T}_{1}$ - Manual harvesting and manual threshing, $\mathrm{T}_{2}$ - Manual harvesting and mechanical threshing and $\mathrm{T}_{3}$ - Combine harvester

Table 4: Effect of Accelerated Ageing on Dry Matter Production (g / 10 Seedlings) of Manually and Mechanically Harvested and Threshed Rice Varieties

\begin{tabular}{|c|c|c|c|c|c|c|c|c|c|c|c|c|c|}
\hline \multirow{2}{*}{ Treatments } & \multicolumn{4}{|c|}{ CO51 (V1) } & \multicolumn{4}{|c|}{ CR1009 Sub 1 (V2) } & \multicolumn{4}{|c|}{ Improved White Ponni (V3) } & \multirow{2}{*}{$\begin{array}{l}\text { Grand } \\
\text { Mean }\end{array}$} \\
\hline & $\mathrm{T}_{1}$ & $\mathrm{~T}_{2}$ & $\mathrm{~T}_{3}$ & Mean & $\mathrm{T}_{1}$ & $\mathrm{~T}_{2}$ & $\mathrm{~T}_{3}$ & Mean & $\mathrm{T}_{1}$ & $\mathrm{~T}_{2}$ & $\mathrm{~T}_{3}$ & Mean & \\
\hline $\mathrm{D}_{1}$-control & 0.121 & 0.120 & 0.120 & 0.120 & 0.151 & 0.141 & 0.149 & 0.147 & 0.111 & 0.114 & 0.112 & 0.112 & 0.127 \\
\hline$D_{2}$-Acceleratedly aged for 1 day & 0.121 & 0.114 & 0.119 & 0.118 & 0.166 & 0.149 & 0.160 & 0.158 & 0.117 & 0.111 & 0.116 & 0.115 & 0.130 \\
\hline $\mathrm{D}_{3}$-Acceleratedly aged for 2 days & 0.111 & 0.117 & 0.118 & 0.115 & 0.142 & 0.147 & 0.139 & 0.143 & 0.111 & 0.117 & 0.118 & 0.115 & 0.124 \\
\hline $\mathrm{D}_{4}$ - Acceleratedly aged for 3 days & 0.115 & 0.117 & 0.116 & 0.116 & 0.157 & 0.147 & 0.155 & 0.153 & 0.107 & 0.113 & 0.111 & 0.110 & 0.126 \\
\hline$D_{5}$-Acceleratedly aged for 4 days & 0.122 & 0.116 & 0.113 & 0.117 & 0.154 & 0.146 & 0.141 & 0.147 & 0.115 & 0.111 & 0.113 & 0.113 & 0.126 \\
\hline $\mathrm{D}_{6}$-Aacceleratedly aged for 5 days & 0.111 & 0.118 & 0.115 & 0.115 & 0.154 & 0.142 & 0.147 & 0.148 & 0.110 & 0.114 & 0.117 & 0.114 & 0.125 \\
\hline $\mathrm{D}_{7}$-Acceleratedly aged for 6 days & 0.119 & 0.113 & 0.123 & 0.118 & 0.161 & 0.153 & 0.157 & 0.157 & 0.112 & 0.115 & 0.114 & 0.114 & 0.130 \\
\hline $\mathrm{D}_{8}$-Acceleratedly & 0.117 & 0.116 & 0.116 & 0.116 & 0.161 & 0.154 & 0.161 & 0.159 & 0.115 & 0.114 & 0.1 & 14 & 0.130 \\
\hline $\mathrm{D}_{9}$-Acceleratedly & 0.112 & 0.113 & 0.116 & 0.114 & 0.161 & 0.147 & 0.160 & 0.156 & 0.114 & 0.116 & 0.1 & 17 & 0.129 \\
\hline $\mathrm{D}_{10}$-Acceleratedly & 0.115 & 0.120 & 0.116 & 0.117 & 0.150 & 0.141 & 0.156 & 0.149 & 0.117 & 0.112 & 0.1 & 17 & 0.128 \\
\hline $\mathrm{D}_{11}$-Acceleratedly aged for 10 days & 122 & 0.106 & 0.130 & 0.119 & 0.158 & 0.144 & 0.147 & 0.1 & 0.116 & 0.1 & 0.1 & & 0.129 \\
\hline $\mathrm{D}_{12}$-Acceleratedly aged for 11 days & 0.114 & 0.116 & 0.100 & 0.110 & 0.153 & 0.156 & 0.156 & 0.155 & 0.100 & 0.099 & 0.101 & 0.100 & 0.122 \\
\hline $\mathrm{D}_{13}$-Acceleratedly aged for 12 days & 0.114 & 0.115 & 0.117 & 0.115 & 0.126 & 0.136 & 0.120 & 0.127 & 0.099 & 0.097 & 0.098 & 0.098 & 0.114 \\
\hline $\mathrm{D}_{14}$-Acceleratedly aged for 13 days & 0.121 & 0.114 & 0.114 & 0.116 & 0.136 & 0.139 & 0.135 & 0.137 & 0.105 & 0.097 & 0.099 & 0.100 & 0.118 \\
\hline$D_{15}$-Acceleratedly aged for 14 days & 0.114 & 0.117 & 0.113 & 0.115 & 0.138 & 0.132 & 0.135 & 0.135 & 0.091 & 0.090 & 0.090 & 0.090 & 0.113 \\
\hline$D_{16}$-Acceleratedly aged for 15 days & 0.118 & 0.119 & 0.121 & 0.119 & 0.129 & 0.135 & 0.140 & 0.135 & 0.107 & 0.108 & 0.108 & 0.108 & 0.121 \\
\hline$D_{17}$-Acceleratedly aged for 16 days & 0.120 & 0.118 & 0.120 & 0.119 & 0.121 & 0.129 & 0.123 & 0.124 & 0.108 & 0.109 & 0.103 & 0.107 & 0.117 \\
\hline $\mathrm{D}_{18}$-Acceleratedly aged for 17 days & 0.116 & 0.115 & 0.120 & 0.117 & 0.131 & 0.129 & 0.126 & 0.129 & 0.105 & 0.036 & 0.100 & 0.080 & 0.109 \\
\hline $\mathrm{D}_{19}$-Acceleratedly aged for 18 days & 0.100 & 0.114 & 0.113 & 0.109 & 0.122 & 0.132 & 0.126 & 0.127 & 0.108 & 0.000 & 0.056 & 0.055 & 0.097 \\
\hline $\mathrm{D}_{20}$-Acceleratedly aged for 19 days & 0.112 & 0.108 & 0.113 & 0.111 & 0.131 & 0.131 & 0.135 & 0.132 & 0.080 & 0.000 & 0.000 & 0.027 & 0.090 \\
\hline $\mathrm{D}_{21}$-Acceleratedly aged for 20 days & 0.108 & 0.100 & 0.101 & 0.103 & 0.128 & 0.128 & 0.129 & 0.128 & 0.000 & 0.000 & 0.000 & 0.000 & 0.077 \\
\hline \multirow[t]{3}{*}{ Mean } & 0.115 & 0.115 & 0.116 & 0.115 & 0.144 & 0.141 & 0.143 & 0.143 & 0.102 & 0.090 & 0.097 & 0.096 & 0.118 \\
\hline & T1 & 0.121 & & $\mathrm{~T} 2$ & 0.115 & & T3 & 0.118 & & & & & \\
\hline & \multicolumn{2}{|c|}{$\mathrm{V}$} & \multicolumn{2}{|c|}{$\mathrm{T}$} & $\mathrm{D}$ & & VT & \multicolumn{2}{|c|}{ TD } & \multicolumn{3}{|c|}{ VD } & VTD \\
\hline SEd & \multicolumn{2}{|c|}{0.0008} & \multicolumn{2}{|c|}{0.0008} & 0.0021 & & 0.0013 & \multicolumn{2}{|c|}{0.0036} & \multicolumn{3}{|c|}{0.0036} & 0.0062 \\
\hline $\mathrm{CD}(\mathrm{P}=0.05)$ & \multicolumn{2}{|c|}{0.0015} & 0.001 & & 0.0040 & & 0.0026 & & .0070 & & 0.0070 & & 0.0121 \\
\hline
\end{tabular}

$\mathrm{T}_{1}$ - Manual harvesting and manual threshing, $\mathrm{T}_{2}$ - Manual harvesting and mechanical threshing and $\mathrm{T}_{3}$ - Combine harvester 
Table 5: Effect of Accelerated Ageing on Vigour Index of Manually and Mechanically Harvested and Threshed Rice Varieties

\begin{tabular}{|c|c|c|c|c|c|c|c|c|c|c|c|c|c|}
\hline \multirow{2}{*}{ Treatments } & \multicolumn{4}{|c|}{ CO51 (V1) } & \multicolumn{4}{|c|}{ CR1009 Sub 1 (V2) } & \multicolumn{4}{|c|}{ Improved White Ponni (V3) } & \multirow{2}{*}{$\begin{array}{l}\text { Grand } \\
\text { Mean }\end{array}$} \\
\hline & $\mathrm{T}_{1}$ & $\mathrm{~T}_{2}$ & $T_{3}$ & Mean & $\mathrm{T}_{1}$ & $\mathrm{~T}_{2}$ & $T_{3}$ & Mean & $\mathrm{T}_{1}$ & $\mathrm{~T}_{2}$ & $T_{3}$ & Mean & \\
\hline $\mathrm{D}_{1}$-control & 3402 & 3192 & 3275 & 3290 & 3386 & 3207 & 3301 & 3298 & 3444 & 3189 & 3279 & 3304 & 3297 \\
\hline$D_{2}$-Acceleratedly aged for 1 day & 3232 & 2953 & 3024 & 3070 & 3209 & 3013 & 3098 & 3107 & 3139 & 2836 & 3018 & 2998 & 3058 \\
\hline $\mathrm{D}_{3}$-Acceleratedly aged for 2 days & 3036 & 2755 & 2871 & 2887 & 3102 & 2808 & 2945 & 2952 & 2940 & 2560 & 2909 & 2803 & 2881 \\
\hline $\mathrm{D}_{4}$ - Acceleratedly aged for 3 days & 2815 & 2458 & 2602 & 2625 & 3004 & 2637 & 2749 & 2797 & 2624 & 2360 & 2672 & 2552 & 2658 \\
\hline$D_{5}$-Acceleratedly aged for 4 days & 2610 & 2314 & 2434 & 2453 & 2847 & 2543 & 2674 & 2688 & 2445 & 2227 & 2521 & 2398 & 2513 \\
\hline $\mathrm{D}_{6}$-Aacceleratedly aged for 5 days & 2432 & 2179 & 2255 & 2289 & 2694 & 2424 & 2549 & 2556 & 2284 & 1987 & 2220 & 2164 & 2336 \\
\hline $\mathrm{D}_{7}$-Acceleratedly aged for 6 days & 2309 & 1921 & 2086 & 2105 & 2572 & 2300 & 2461 & 2444 & 2132 & 1813 & 1968 & 1971 & 2174 \\
\hline $\mathrm{D}_{8}$-Acceleratedly aged for 7 days & 2175 & 1787 & 1930 & 1964 & 2406 & 2090 & 2287 & 2261 & 1901 & 1689 & 1852 & 1814 & 2013 \\
\hline $\mathrm{D}_{9}$-Acceleratedly aged for 8 days & 2064 & 1620 & 1815 & 1833 & 2290 & 1906 & 2143 & 2113 & 1721 & 1417 & 1674 & 1604 & 1850 \\
\hline$D_{10}$-Acceleratedly aged for 9 days & 1920 & 1451 & 1629 & 1667 & 2173 & 1772 & 1943 & 1963 & 1466 & 1222 & 1442 & 1377 & 1669 \\
\hline$D_{11}$-Acceleratedly aged for 10 days & 1799 & 1330 & 1480 & 1536 & 2015 & 1612 & 1832 & 1820 & 1275 & 1003 & 1232 & 1170 & 1509 \\
\hline $\mathrm{D}_{12}$-Acceleratedly aged for 11 days & 1647 & 1183 & 1282 & 1371 & 1864 & 1476 & 1674 & 1671 & 1103 & 856 & 1084 & 1014 & 1352 \\
\hline$D_{13}$-Acceleratedly aged for 12 days & 1565 & 1030 & 1188 & 1261 & 1684 & 1348 & 1533 & 1522 & 933 & 744 & 955 & 877 & 1220 \\
\hline$D_{14}$-Acceleratedly aged for 13 days & 1417 & 939 & 1054 & 1137 & 1500 & 1234 & 1360 & 1365 & 777 & 598 & 707 & 694 & 1065 \\
\hline$D_{15}$-Acceleratedly aged for 14 days & 1269 & 803 & 931 & 1001 & 1306 & 1123 & 1229 & 1219 & 655 & 431 & 543 & 543 & 921 \\
\hline$D_{16}$-Acceleratedly aged for 15 days & 1193 & 713 & 792 & 899 & 1221 & 1008 & 1093 & 1107 & 533 & 293 & 392 & 406 & 804 \\
\hline$D_{17}$-Acceleratedly aged for 16 days & 1072 & 597 & 710 & 793 & 1117 & 915 & 1015 & 1016 & 424 & 145 & 276 & 282 & 697 \\
\hline $\mathrm{D}_{18}$-Acceleratedly aged for 17 days & 924 & 504 & 596 & 675 & 1005 & 844 & 872 & 907 & 237 & 54 & 193 & 161 & 581 \\
\hline $\mathrm{D}_{19}$-Acceleratedly aged for 18 days & 760 & 433 & 486 & 560 & 889 & 717 & 750 & 785 & 131 & 0 & 34 & 55 & 467 \\
\hline $\mathrm{D}_{20}$-Acceleratedly aged for 19 days & 534 & 383 & 435 & 451 & 803 & 594 & 657 & 685 & 64 & 0 & 0 & 21 & 386 \\
\hline $\mathrm{D}_{21}$-Acceleratedly aged for 20 days & 463 & 278 & 333 & 358 & 710 & 508 & 544 & 587 & 0 & 0 & 0 & 0 & 315 \\
\hline \multirow[t]{3}{*}{ Mean } & 1840 & 1468 & 1581 & 1630 & 1990 & 1718 & 1843 & 1851 & 1439 & 1211 & 1380 & 1343 & 1608 \\
\hline & T1 & 1757 & & T2 & 1465 & & T3 & 1601 & & & & & \\
\hline & \multicolumn{2}{|c|}{$\mathrm{V}$} & \multicolumn{2}{|c|}{$\mathrm{T}$} & \multicolumn{2}{|l|}{$\mathrm{D}$} & VT & \multirow{2}{*}{\multicolumn{2}{|c|}{$\frac{\text { TD }}{87409}$}} & \multirow{2}{*}{\multicolumn{3}{|c|}{$\frac{\text { VD }}{87409}$}} & VTD \\
\hline SEd & \multirow{2}{*}{\multicolumn{2}{|c|}{$\begin{array}{l}19.0 / 4 \\
37.465\end{array}$}} & \multirow{2}{*}{\multicolumn{2}{|c|}{$\begin{array}{l}19.074 \\
37.465\end{array}$}} & 50.466 & & 33.038 & & & & & & 151.398 \\
\hline $\mathrm{CD}(\mathrm{P}=0.05)$ & & & & & 99.124 & & 64.892 & \multicolumn{2}{|c|}{ NS } & \multicolumn{3}{|c|}{171.687} & NS \\
\hline
\end{tabular}

$\mathrm{T}_{1}$ - Manual harvesting and manual threshing, $\mathrm{T}_{2}$ - Manual harvesting and mechanical threshing and $\mathrm{T}_{3}$ - Combine harvester

Table 6: Effect of Accelerated Ageing on Electrical Conductivity of Seed Leachates $\left(\mu \mathrm{Sm}^{-1}\right)$ of Manually and Mechanically Harvested and Threshed Rice Varieties

\begin{tabular}{|c|c|c|c|c|c|c|c|c|c|c|c|c|c|}
\hline \multirow{2}{*}{ Treatments } & \multicolumn{4}{|c|}{$\operatorname{CO51}(\mathrm{V} 1)$} & \multicolumn{4}{|c|}{ CR1009 Sub 1 (V2) } & \multicolumn{4}{|c|}{ Improved White Ponni (V3) } & \multirow{2}{*}{$\begin{array}{l}\text { Grand } \\
\text { Mean }\end{array}$} \\
\hline & $\mathrm{T}_{1}$ & $\mathrm{~T}_{2}$ & $\mathrm{~T}_{3}$ & Mean & $\mathrm{T}_{1}$ & $\mathrm{~T}_{2}$ & $T_{3}$ & Mean & $\mathrm{T}_{1}$ & $\mathrm{~T}_{2}$ & $T_{3}$ & Mean & \\
\hline $\mathrm{D}_{1}$-control & 57.3 & 59.8 & 59.1 & 58.7 & 65.3 & 67.9 & 67.8 & 67.0 & 53.2 & 55.6 & 55.2 & 54.7 & 60.1 \\
\hline $\mathrm{D}_{2}$-Acceleratedly aged for 1 day & 59.8 & 62.4 & 61.8 & 61.3 & 68.2 & 73.4 & 72.6 & 71.4 & 56.7 & 59.2 & 59.8 & 58.6 & 63.8 \\
\hline $\mathrm{D}_{3}$-Acceleratedly aged for 2 days & 62.1 & 65.4 & 64.2 & 63.9 & 72.6 & 78.1 & 76.1 & 75.6 & 63.4 & 61.5 & 64.7 & 63.2 & 67.6 \\
\hline $\mathrm{D}_{4}$ - Acceleratedly aged for 3 days & 65.7 & 68.1 & 67.0 & 66.9 & 79.1 & 81.3 & 80.6 & 80.3 & 64.5 & 65.4 & 69.4 & 66.4 & 71.2 \\
\hline $\mathrm{D}_{5}$-Acceleratedly aged for 4 days & 68.9 & 71.6 & 70.5 & 70.3 & 83.7 & 85.6 & 84.6 & 84.6 & 66.3 & 67.5 & 72.3 & 68.7 & 74.6 \\
\hline $\mathrm{D}_{6}$-Aacceleratedly aged for 5 days & 72.5 & 76.8 & 73.8 & 74.4 & 87.5 & 89.9 & 88.1 & 88.5 & 70.7 & 72.8 & 76.4 & 73.3 & 78.7 \\
\hline $\mathrm{D}_{7}$-Acceleratedly aged for 6 days & 77.4 & 79.9 & 77.9 & 78.4 & 92.6 & 94.7 & 92.4 & 93.2 & 75.9 & 78.5 & 79.2 & 77.9 & 83.2 \\
\hline $\mathrm{D}_{8}$-Acceleratedly aged for 7 days & 80.6 & 85.6 & 81.6 & 82.6 & 97.3 & 99.5 & 96.4 & 97.7 & 78.1 & 82.4 & 82.3 & 80.9 & 87.1 \\
\hline$D_{9}$-Acceleratedly aged for 8 days & 84.3 & 89.2 & 85.4 & 86.3 & 100.9 & 103.4 & 101.2 & 101.8 & 80.3 & 87.1 & 85.1 & 84.2 & 90.8 \\
\hline $\mathrm{D}_{10}$-Acceleratedly aged for 9 days & 87.8 & 93.5 & 89.0 & 90.1 & 103.7 & 108.9 & 105.4 & 106.0 & 84.6 & 92.7 & 89.9 & 89.1 & 95.1 \\
\hline $\mathrm{D}_{11}$-Acceleratedly aged for 10 days & 91.5 & 97.6 & 93.1 & 94.1 & 107.2 & 112.1 & 110.8 & 110.0 & 88.3 & 96.0 & 93.4 & 92.6 & 98.9 \\
\hline $\mathrm{D}_{12}$-Acceleratedly aged for 11 days & 95.9 & 101.6 & 96.2 & 97.9 & 110.0 & 115.7 & 113.8 & 113.2 & 91.5 & 99.8 & 98.0 & 96.4 & 102.5 \\
\hline $\mathrm{D}_{13}$-Acceleratedly aged for 12 days & 99.4 & 105.7 & 100.3 & 101.8 & 114.4 & 118.2 & 116.1 & 116.2 & 95.7 & 103.6 & 101.5 & 100.3 & 106.1 \\
\hline $\mathrm{D}_{14}$-Acceleratedly aged for 13 days & 103.8 & 109.5 & 103.4 & 105.6 & 117.1 & 122.3 & 120.3 & 119.9 & 99.2 & 108.8 & 104.8 & 104.3 & 109.9 \\
\hline $\mathrm{D}_{15}$-Acceleratedly aged for 14 days & 107.1 & 113.7 & 108.2 & 109.7 & 121.7 & 127.8 & 125.6 & 125.0 & 102.3 & 113.4 & 109.2 & 108.3 & 114.3 \\
\hline $\mathrm{D}_{16}$-Acceleratedly aged for 15 days & 111.6 & 117.6 & 113.4 & 114.2 & 125.4 & 131.5 & 129.5 & 128.8 & 105.8 & 118.5 & 111.5 & 111.9 & 118.3 \\
\hline $\mathrm{D}_{17}$-Acceleratedly aged for 16 days & 116.8 & 122.3 & 119.9 & 119.7 & 129.6 & 137.8 & 134.1 & 133.8 & 109.7 & 121.4 & 114.7 & 115.3 & 122.9 \\
\hline $\mathrm{D}_{18}$-Acceleratedly aged for 17 days & 120.7 & 126.7 & 125.2 & 124.2 & 134.3 & 142.9 & 139.9 & 139.0 & 112.0 & 125.7 & 117.1 & 118.3 & 127.2 \\
\hline $\mathrm{D}_{19}$-Acceleratedly aged for 18 days & 125.1 & 130.4 & 129.7 & 128.4 & 139.4 & 149.5 & 143.5 & 144.1 & 115.6 & 135.0 & 126.4 & 125.7 & 132.7 \\
\hline $\mathrm{D}_{20}$-Acceleratedly aged for 19 days & 131.4 & 135.9 & 134.3 & 133.9 & 144.7 & 156.2 & 148.7 & 149.9 & 118.6 & 141.6 & 132.1 & 130.8 & 138.2 \\
\hline $\mathrm{D}_{21}$-Acceleratedly aged for 20 days & 135.6 & 140.7 & 138.4 & 138.2 & 147.9 & 162.7 & 154.6 & 155.1 & 126.3 & 149.2 & 137.8 & 137.8 & 143.7 \\
\hline \multirow[t]{3}{*}{ Mean } & 93.1 & 97.8 & 94.9 & 95.3 & 106.8 & 112.4 & 109.6 & 109.6 & 88.5 & 96.9 & 94.3 & 93.3 & 99.4 \\
\hline & T1 & 96.1 & & T2 & 102.4 & & T3 & 99.6 & & & & & \\
\hline & \multicolumn{2}{|c|}{$\mathrm{V}$} & \multicolumn{2}{|c|}{$\mathrm{T}$} & \multicolumn{2}{|l|}{$\mathrm{D}$} & VT & \multicolumn{2}{|c|}{ TD } & \multicolumn{3}{|c|}{ VD } & VTD \\
\hline SEd & \multicolumn{2}{|c|}{0.2559} & \multicolumn{2}{|c|}{0.2559} & \multicolumn{2}{|l|}{0.6770} & 0.4432 & \multicolumn{2}{|c|}{1.1726} & \multicolumn{3}{|c|}{1.1727} & 2.0311 \\
\hline $\mathrm{CD}(\mathrm{P}=0.05)$ & \multicolumn{2}{|c|}{0.5032} & \multicolumn{2}{|c|}{0.5032} & 1.3313 & & 0.8715 & \multicolumn{2}{|c|}{2.3058} & \multicolumn{3}{|c|}{2.3058} & 3.9937 \\
\hline
\end{tabular}

$\mathrm{T}_{1}$ - Manual harvesting and manual threshing, $\mathrm{T}_{2}$ - Manual harvesting and mechanical threshing and $\mathrm{T}_{3}$ - Combine harvester 
Table 7: Effect of Accelerated Ageing on Dehydrogenase Activity (OD Value/10 Seeds) of Manually and Mechanically Harvested and Threshed Rice Varieties

\begin{tabular}{|c|c|c|c|c|c|c|c|c|c|c|c|c|c|}
\hline \multirow{2}{*}{ Treatments } & \multicolumn{4}{|c|}{ CO51 (V1) } & \multicolumn{4}{|c|}{ CR1009 Sub 1 (V2) } & \multicolumn{4}{|c|}{ Improved White Ponni (V3) } & \multirow{2}{*}{$\begin{array}{l}\text { Grand } \\
\text { Mean }\end{array}$} \\
\hline & $\mathrm{T}_{1}$ & $T_{2}$ & $T_{3}$ & Mean & $\mathrm{T}_{1}$ & $\mathrm{~T}_{2}$ & $T_{3}$ & Mean & $\mathrm{T}_{1}$ & $\mathrm{~T}_{2}$ & $T_{3}$ & Mean & \\
\hline $\mathrm{D}_{1}$-control & 0.842 & 0.829 & 0.832 & 0.834 & 0.934 & 0.930 & 0.931 & 0.932 & 0.820 & 0.817 & 0.819 & 0.819 & 0.862 \\
\hline $\mathrm{D}_{2}$-Acceleratedly aged for 1 day & 0.837 & 0.825 & 0.825 & 0.829 & 0.929 & 0.927 & 0.928 & 0.928 & 0.816 & 0.814 & 0.815 & 0.815 & 0.857 \\
\hline $\mathrm{D}_{3}$-Acceleratedly aged for 2 days & 0.833 & 0.821 & 0.818 & 0.824 & 0.925 & 0.923 & 0.925 & 0.924 & 0.811 & 0.809 & 0.810 & 0.810 & 0.853 \\
\hline $\mathrm{D}_{4}$ - Acceleratedly aged for 3 days & 0.829 & 0.818 & 0.820 & 0.822 & 0.921 & 0.919 & 0.921 & 0.920 & 0.807 & 0.805 & 0.805 & 0.806 & 0.849 \\
\hline $\mathrm{D}_{5}$-Acceleratedly aged for 4 days & 0.824 & 0.814 & 0.817 & 0.818 & 0.917 & 0.915 & 0.918 & 0.917 & 0.802 & 0.800 & 0.801 & 0.801 & 0.845 \\
\hline $\mathrm{D}_{6}$-Aacceleratedly aged for 5 days & 0.820 & 0.810 & 0.812 & 0.814 & 0.913 & 0.910 & 0.914 & 0.912 & 0.797 & 0.795 & 0.796 & 0.796 & 0.841 \\
\hline $\mathrm{D}_{7}$-Acceleratedly aged for 6 days & 0.817 & 0.806 & 0.807 & 0.810 & 0.909 & 0.905 & 0.911 & 0.908 & 0.794 & 0.791 & 0.793 & 0.793 & 0.837 \\
\hline $\mathrm{D}_{8}$-Acceleratedly aged for 7 days & 0.812 & 0.800 & 0.803 & 0.805 & 0.905 & 0.901 & 0.906 & 0.904 & 0.791 & 0.787 & 0.790 & 0.789 & 0.833 \\
\hline $\mathrm{D}_{9}$-Acceleratedly aged for 8 days & 0.808 & 0.796 & 0.798 & 0.801 & 0.901 & 0.897 & 0.900 & 0.899 & 0.788 & 0.783 & 0.785 & 0.785 & 0.828 \\
\hline $\mathrm{D}_{10}$-Acceleratedly aged for 9 days & 0.803 & 0.791 & 0.791 & 0.795 & 0.897 & 0.892 & 0.897 & 0.895 & 0.783 & 0.779 & 0.781 & 0.781 & 0.824 \\
\hline $\mathrm{D}_{11}$-Acceleratedly aged for 10 days & 0.799 & 0.788 & 0.784 & 0.790 & 0.893 & 0.888 & 0.894 & 0.892 & 0.779 & 0.775 & 0.778 & 0.777 & 0.820 \\
\hline $\mathrm{D}_{12}$-Acceleratedly aged for 11 days & 0.795 & 0.782 & 0.779 & 0.785 & 0.889 & 0.881 & 0.890 & 0.887 & 0.774 & 0.771 & 0.773 & 0.773 & 0.815 \\
\hline $\mathrm{D}_{13}$-Acceleratedly aged for 12 days & 0.791 & 0.767 & 0.775 & 0.778 & 0.884 & 0.877 & 0.886 & 0.882 & 0.770 & 0.768 & 0.769 & 0.769 & 0.810 \\
\hline $\mathrm{D}_{14}$-Acceleratedly aged for 13 days & 0.786 & 0.760 & 0.770 & 0.772 & 0.880 & 0.871 & 0.882 & 0.878 & 0.767 & 0.762 & 0.764 & 0.764 & 0.805 \\
\hline $\mathrm{D}_{15}$-Acceleratedly aged for 14 days & 0.779 & 0.755 & 0.766 & 0.767 & 0.875 & 0.867 & 0.873 & 0.872 & 0.762 & 0.758 & 0.760 & 0.760 & 0.799 \\
\hline $\mathrm{D}_{16}$-Acceleratedly aged for 15 days & 0.774 & 0.751 & 0.761 & 0.762 & 0.871 & 0.862 & 0.868 & 0.867 & 0.758 & 0.751 & 0.753 & 0.754 & 0.794 \\
\hline $\mathrm{D}_{17}$-Acceleratedly aged for 16 days & 0.768 & 0.747 & 0.757 & 0.757 & 0.868 & 0.857 & 0.864 & 0.863 & 0.754 & 0.746 & 0.749 & 0.750 & 0.790 \\
\hline $\mathrm{D}_{18}$-Acceleratedly aged for 17 days & 0.762 & 0.742 & 0.752 & 0.752 & 0.863 & 0.853 & 0.860 & 0.859 & 0.750 & 0.740 & 0.744 & 0.745 & 0.785 \\
\hline$D_{19}$-Acceleratedly aged for 18 days & 0.759 & 0.737 & 0.748 & 0.748 & 0.858 & 0.849 & 0.855 & 0.854 & 0.746 & 0.736 & 0.739 & 0.740 & 0.781 \\
\hline $\mathrm{D}_{20}$-Acceleratedly aged for 19 days & 0.754 & 0.732 & 0.742 & 0.743 & 0.855 & 0.845 & 0.848 & 0.849 & 0.741 & 0.730 & 0.733 & 0.735 & 0.776 \\
\hline $\mathrm{D}_{21}$-Acceleratedly aged for 20 days & 0.750 & 0.729 & 0.738 & 0.739 & 0.851 & 0.841 & 0.944 & 0.879 & 0.734 & 0.724 & 0.728 & 0.729 & 0.782 \\
\hline \multirow[t]{3}{*}{ Mean } & 0.797 & 0.781 & 0.785 & 0.788 & 0.892 & 0.886 & 0.896 & 0.891 & 0.778 & 0.773 & 0.775 & 0.776 & 0.818 \\
\hline & T1 & 0.823 & & T2 & 0.814 & & T3 & 0.819 & & & & & \\
\hline & \multicolumn{2}{|c|}{$\mathrm{V}$} & \multicolumn{2}{|l|}{$\mathrm{T}$} & \multicolumn{2}{|l|}{$\mathrm{D}$} & VT & \multicolumn{2}{|r|}{ TD } & \multicolumn{3}{|c|}{$\mathrm{VD}$} & VTD \\
\hline SEd & \multicolumn{2}{|c|}{0.002} & \multicolumn{2}{|c|}{0.002} & \multicolumn{2}{|l|}{0.006} & 0.004 & \multicolumn{2}{|c|}{0.010} & \multicolumn{3}{|c|}{0.010} & 0.020 \\
\hline $\mathrm{CD}(\mathrm{P}=0.05)$ & \multicolumn{2}{|c|}{0.004} & \multicolumn{2}{|c|}{ NS } & 0.011 & & 0.008 & \multicolumn{2}{|c|}{ NS } & \multicolumn{3}{|c|}{ NS } & NS \\
\hline
\end{tabular}

$\mathrm{T}_{1}$ - Manual harvesting and manual threshing, $\mathrm{T}_{2}$ - Manual harvesting and mechanical threshing and $\mathrm{T}_{3}$ - Combine harvester

Table 8: Effect of Accelerated Ageing on $\alpha$ - Amylase Activity (mg Maltose/ min.) of Manually and Mechanically Harvested and Threshed Rice Varieties

\begin{tabular}{|c|c|c|c|c|c|c|c|c|c|c|c|c|c|}
\hline \multirow{2}{*}{ Treatments } & \multicolumn{4}{|c|}{$\operatorname{CO51}(\mathrm{V} 1)$} & \multicolumn{4}{|c|}{ CR1009 Sub 1 (V2) } & \multicolumn{4}{|c|}{ Improved White Ponni (V3) } & \multirow{2}{*}{$\begin{array}{l}\text { Grand } \\
\text { Mean }\end{array}$} \\
\hline & $\mathbf{T}_{1}$ & $\mathrm{~T}_{2}$ & $T_{3}$ & Mean & $\mathbf{T}_{1}$ & $\mathrm{~T}_{2}$ & $\mathbf{T}_{3}$ & Mean & $T_{1}$ & $\mathrm{~T}_{2}$ & $\mathbf{T}_{3}$ & Mean & \\
\hline $\mathrm{D}_{1}$-control & 1.963 & 1.950 & 1.954 & 1.956 & 2.231 & 2.220 & 2.225 & 2.225 & 2.145 & 2.110 & 2.129 & 2.128 & 2.103 \\
\hline $\mathrm{D}_{2}$-Acceleratedly aged for 1 day & 1.903 & 1.891 & 1.899 & 1.898 & 2.186 & 2.153 & 2.169 & 2.169 & 2.091 & 2.046 & 2.058 & 2.065 & 2.044 \\
\hline $\mathrm{D}_{3}$-Acceleratedly aged for 2 days & 1.866 & 1.826 & 1.839 & 1.844 & 2.093 & 2.068 & 2.076 & 2.079 & 1.995 & 1.963 & 1.976 & 1.978 & 1.967 \\
\hline $\mathrm{D}_{4}$ - Acceleratedly aged for 3 days & 1.810 & 1.778 & 1.788 & 1.792 & 2.005 & 1.976 & 2.000 & 1.994 & 1.934 & 1.895 & 1.912 & 1.914 & 1.900 \\
\hline $\mathrm{D}_{5}$-Acceleratedly aged for 4 days & 1.782 & 1.708 & 1.730 & 1.740 & 1.972 & 1.934 & 1.962 & 1.956 & 1.886 & 1.821 & 1.864 & 1.857 & 1.851 \\
\hline $\mathrm{D}_{6}$-Aacceleratedly aged for 5 days & 1.724 & 1.672 & 1.692 & 1.696 & 1.909 & 1.890 & 1.895 & 1.898 & 1.812 & 1.782 & 1.803 & 1.799 & 1.798 \\
\hline $\mathrm{D}_{7}$-Acceleratedly aged for 6 days & 1.686 & 1.634 & 1.642 & 1.654 & 1.863 & 1.835 & 1.854 & 1.851 & 1.769 & 1.711 & 1.738 & 1.739 & 1.748 \\
\hline$D_{8}$-Acceleratedly aged for 7 days & 1.611 & 1.582 & 1.600 & 1.598 & 1.808 & 1.788 & 1.795 & 1.797 & 1.706 & 1.675 & 1.689 & 1.690 & 1.695 \\
\hline $\mathrm{D}_{9}$-Acceleratedly aged for 8 days & 1.567 & 1.510 & 1.561 & 1.546 & 1.782 & 1.731 & 1.756 & 1.756 & 1.675 & 1.609 & 1.631 & 1.638 & 1.647 \\
\hline $\mathrm{D}_{10}$-Acceleratedly aged for 9 days & 1.506 & 1.490 & 1.507 & 1.501 & 1.718 & 1.693 & 1.699 & 1.703 & 1.600 & 1.562 & 1.589 & 1.584 & 1.596 \\
\hline $\mathrm{D}_{11}$-Acceleratedly aged for 10 days & 1.489 & 1.441 & 1.489 & 1.473 & 1.689 & 1.622 & 1.645 & 1.652 & 1.559 & 1.495 & 1.522 & 1.525 & 1.550 \\
\hline $\mathrm{D}_{12}$-Acceleratedly aged for 11 days & 1.415 & 1.399 & 1.436 & 1.417 & 1.622 & 1.584 & 1.597 & 1.601 & 1.501 & 1.401 & 1.489 & 1.464 & 1.494 \\
\hline $\mathrm{D}_{13}$-Acceleratedly aged for 12 days & 1.380 & 1.320 & 1.399 & 1.366 & 1.570 & 1.500 & 1.523 & 1.531 & 1.475 & 1.343 & 1.406 & 1.408 & 1.435 \\
\hline $\mathrm{D}_{14}$-Acceleratedly aged for 13 days & 1.331 & 1.285 & 1.351 & 1.322 & 1.504 & 1.453 & 1.469 & 1.475 & 1.415 & 1.268 & 1.353 & 1.345 & 1.381 \\
\hline $\mathrm{D}_{15}$-Acceleratedly aged for 14 days & 1.295 & 1.203 & 1.301 & 1.266 & 1.451 & 1.410 & 1.425 & 1.429 & 1.363 & 1.198 & 1.271 & 1.277 & 1.324 \\
\hline $\mathrm{D}_{16}$-Acceleratedly aged for 15 days & 1.252 & 1.172 & 1.256 & 1.227 & 1.398 & 1.363 & 1.382 & 1.381 & 1.296 & 1.125 & 1.193 & 1.205 & 1.271 \\
\hline $\mathrm{D}_{17}$-Acceleratedly aged for 16 days & 1.205 & 1.111 & 1.195 & 1.170 & 1.329 & 1.311 & 1.322 & 1.321 & 1.229 & 1.031 & 1.101 & 1.120 & 1.204 \\
\hline $\mathrm{D}_{18}$-Acceleratedly aged for 17 days & 1.186 & 1.084 & 1.109 & 1.126 & 1.276 & 1.231 & 1.245 & 1.251 & 1.187 & 0.943 & 0.991 & 1.040 & 1.139 \\
\hline $\mathrm{D}_{19}$-Acceleratedly aged for 18 days & 1.121 & 1.025 & 1.067 & 1.071 & 1.212 & 1.181 & 1.198 & 1.197 & 1.084 & 0.821 & 0.910 & 0.938 & 1.069 \\
\hline $\mathrm{D}_{20}$-Acceleratedly aged for 19 days & 1.092 & 0.981 & 1.011 & 1.028 & 1.183 & 1.101 & 1.125 & 1.136 & 0.973 & 0.661 & 0.868 & 0.834 & 0.999 \\
\hline $\mathrm{D}_{21}$-Acceleratedly aged for 20 days & 1.049 & 0.902 & 0.976 & 0.976 & 1.122 & 1.022 & 1.049 & 1.064 & 0.892 & 0.582 & 0.754 & 0.743 & 0.928 \\
\hline \multirow[t]{3}{*}{ Mean } & 1.487 & 1.427 & 1.467 & 1.460 & 1.663 & 1.622 & 1.639 & 1.641 & 1.552 & 1.431 & 1.488 & 1.490 & 1.531 \\
\hline & T1 & 1.567 & & T2 & 1.493 & & T3 & 1.531 & & & & & \\
\hline & \multicolumn{2}{|c|}{$\mathrm{V}$} & \multicolumn{2}{|l|}{$\mathrm{T}$} & \multicolumn{2}{|l|}{$\mathrm{D}$} & VT & \multicolumn{2}{|c|}{ TD } & \multicolumn{3}{|c|}{ VD } & VTD \\
\hline SEd & \multirow{2}{*}{\multicolumn{2}{|c|}{0.004}} & \multicolumn{2}{|c|}{0.004} & 0.011 & & 0.007 & \multicolumn{2}{|c|}{0.020} & \multicolumn{3}{|c|}{0.020} & 0.034 \\
\hline $\mathrm{CD}(\mathrm{P}=0.05)$ & & & \multicolumn{2}{|c|}{0.008} & 0.022 & & 0.015 & \multicolumn{2}{|c|}{0.038} & \multicolumn{3}{|c|}{0.038} & NS \\
\hline
\end{tabular}

$\mathrm{T}_{1}$ - Manual harvesting and manual threshing, $\mathrm{T}_{2}$ - Manual harvesting and mechanical threshing and $\mathrm{T}_{3}$ - Combine harvester 